\title{
SIGNALLING SITES OF CONTENTION IN JUDICIAL DISCOURSE. AN EXPLORATORY CORPUS-BASED ANALYSIS OF SELECTED STANCE NOUNS IN US SUPREME COURT OPINIONS AND POLAND'S CONSTITUTIONAL TRIBUNAL JUDGMENTS
}

\author{
Stanisław GOŹDŹ-ROSZKOWSKI \\ Department of Translation Studies \\ University of Łódź \\ roszkowski@uni.lodz.pl
}

\begin{abstract}
This paper adopts a comparative, corpus-based perspective to examine the language of judicial justification. Based on substantial corpus data, the study explores one of the linguistics resources, i.e. head nouns (e.g. assumption, belief, notion, etc.) followed by a nominal complement in the form of that-clause in two comparable legal settings: the opinions given in the United States Supreme Court and the judgements handed down by Poland's Constitutional Tribunal. The findings corroborate the results of previous research which shows that nouns found in this pattern are used to perform various discourse functions but evaluation plays a central role in judicial writing and these nouns are used to signal sites of contentions. The
\end{abstract}




\section{Stanisław GOŹDŹ-ROSZKOWSKI: Signalling Sites...}

study reveals the general similarity between the two sets of data suggesting that American and Polish judicial writing is underpinned by essentially the same epistemological assumptions. Yet, there are some differences in the way the nouns behave phraseologically. Polish nouns tend to show less collocational variation and they are found performing fewer discourse functions.

Key words: evaluation, stance, judicial discourse, legal justification, US Supreme Court, Constitutional Tribunal

Streszczenie: Niniejszy artykuł ukazuje próbę wykorzystania metodologii korpusowej w celu badania języka uzasadnien decyzji stosowania prawa. Przedmiotem analizy jest użycie grupy rzeczowników takich jak przypuszczenie, pogląd czy sugestia w konstrukcji przed spójnikiem that, a więc kontrolujących zdania podrzędne dopełnieniowe. Celem badania jest zbadanie funkcji jakie rzeczowniki $\mathrm{w}$ tej konstrukcji pełnią $\mathrm{w}$ dyskursie uzasadnień sądowych. Przyjęta hipoteza zakładała, że jedną z funkcji może być wartościowanie. Przedstawione $\mathrm{w}$ artykule wyniki potwierdzają, że sędziowie, zarówno amerykańscy jak i polscy, posługują się chętnie tego typu wyrażeniami w celu dokonania oceny argumentów zgłoszonych przez sędziów rozpatrujących sprawę w niższej instancji, strony procesowe, jak również innych sędziów spośród składu orzekającego. Bliższa analiza ukazuje również, iż rzeczowniki użyte $\mathrm{w}$ uzasadnieniach Trybunału Konstytucyjnego charakteryzują się mniejszym zróżnicowaniem kolokacyjnym oraz pełnią mniej funkcji $\mathrm{w}$ dyskursie niż ich angielskie odpowiedniki.

Słowa kluczowe: dyskurs sądowy, wartościowanie, uzasadnienie, Sąd Najwyższy Stanów Zjednoczonych, Trybunał Konstytucyjny

\section{Introduction}

Apart from making their decisions, judges need to present them in a way that appears fair and objective to all the parties involved as well as to the general public. Justifying a decision seems to be almost as important as the decision itself. And the decisions made by judges often have enormous and far-reaching consequences in people's lives. This paper is concerned with how judges justify their decisions and in doing so how they construct their reasoning. As DiMatteo argues (2015: 513), it is not easy to grasp the "causal 
relationship between judicial reasoning and the justification given for judicial decisions". One aspect shared by both legal argumentation and justification inevitably involves evaluation. In their argumentation, judges, especially in appellate courts, assess the strengths and weaknesses of arguments advanced by various legal actors: lower court judges, procecution, legal counsel, their fellow judges, etc. depending on the type of court and jurisdiction. In doing so they express their stances and align themselves with other institutional interactants. The language that they use to accomplish this task reveals the epistemological beliefs and values of their professional community as well as their personal system of values. This area of specialist language use in institutional settings is signficant and highly relevant to professional practice but at the same time it is complex and methodologically problematic. Its actual verbal realizations can be extremely complex and often elusive since evaluative meanings are expressed overtly or they can be communicated implicitly by relying on shared values and knowledge.

The linguistic aspects of evaluation are most often subsumed within such concepts as appraisal (Martin and White 2005), evaluation (Hunston and Thompson 2000) or stance (e.g. Biber et al. 1999). In this paper I rely on the concepts of evaluation and stance seen from the perspective of Corpus Linguistics methodology in order to explore linguistic resources employed to express evaluation. While there is growing literature on evaluation and stance in the context of a single legal system and language, there is still relatively little research contributing to our uderstanding of how evaluation is done across different legal systems, cultures and languages. This paper reports findings which are part of a larger project which aims at describing the construal of evaluative language in judicial language across different legal languages and cultures. It identifies ways in which evaluations are formulated that are characteristic of judicial opinions in general rather than with regard to individual and idiosyncratic modes of expression. In this study I address this issue by considering one of the linguistics resources, i.e. head nouns (e.g. assumption, belief, notion, etc.) followed by a nominal complement in the form of that-clause in two comparable legal settings: the opinions given in the United States Supreme Court and the judgements handed down by Poland's Constitutional Tribunal. Previous research shows that nouns found in this pattern are used to perform various discourse functions but evaluation plays a central role in judicial writing and these nouns are 
used to signal sites of contentions, i.e. challenged propositions are likely to be labelled as arguments, assumptions, notions or suggestions (Goźdź-Roszkowski and Pontrandolfo 2013; GoźdźRoszkowski forth.). This paper aims to test this hypothesis further by examining the phraseological behaviour of selected nouns in the $\mathrm{N}+$ that grammar pattern in American and Polish judicial discourse.

The paper is structured as follows: the next section explains the key concepts of evaluation and stance and it briefly summarizes existing research into how these linguistic concepts have been applied to study judicial discourse. Section 3 is concerned with the institutional contexts of the United States Supreme Court and the Polish Constitutional Tribunal. This section also shows the macrostructures of a US judicial opinion and a Polish judgment in order to further contextualize legal reasoning and justification as these are embedded within the respective documents. Section 4 presents corpora and the method employed throughout the analysis. This is followed by Results and Discussion and Conclusions.

\section{Evaluation and Stance and their Applications in Judicial Discourse}

As already indicated, evaluation is at the heart of judicial reasoning and justification. Indicating an attitude towards a legal entity, process or interactant is inherent in the acts of persuasion and argumentation, both being an integral part of judicial discourse. A substantial part of judicial opinions involves expressing agreement or disagreement with decisions given by lower courts, opinions expressed by counsel representing the parties, as well as the opinions arrived at by fellow judges from the same bench. Evaluation is the engine of persuasion (Partington et al., 2013: 46) and judges have to persuade that their grounds are right or that the arguments adduced by the defendants or their counsel are wrong. In doing so, they inevitably resort to assessing the merits of arguments they are asked to examine. In the science of linguistics, the term evaluation is usually understood as.

'the broad cover term for the expression of the speaker or writer's attitude or stance towards, viewpoint on, or feelings 


\section{Comparative Legilinguistics 2017/32}

about the entities or propositions that he or she is talking about. That attitude may relate to certainty or obligation or desirability or any of a number of other sets of values' (Thompson and Hunston 2000: 5)

More specifically, evaluation can be characterised as representing types of meaning that tend to be 'subjective' or 'attitudinal', and that may be distinguished from the 'objective' or 'factual'. In the context of judicial argumentation, evaluation can represent an individual position of a single judge (in a dissenting or concurring opinion), the position of a whole court or the majority of judges in a given case. Evaluation is most often used to express a user orientation (it is the user who evaluates) but it also focuses on "values ascribed to the entities and propositions which are evaluated" (Thompson and Hunston 2000: 5). On the other hand, the concept of stance or stance-taking (du Bois 2007), construes an action (taking stance) rather than an entity. The act of (dis)alignment between interactants is perhaps of greater importance (Goźdź-Roszkowski \& Hunston 2016). Viewed against the backdrop of judicial discourse, the judge who takes a stance construes a relationship between themselves and an external entity and simultaneously between themselves and other legal interactant(s), such as other judges from the same bench, lower court judges, counsel, defence counsel, attorney general, etc.

It should be noted that the study of evaluation or stance poses some methodological problems. On the one hand, evaluation may be expressed overtly or explicitly, using recognisably evaluative lexis and/or constructions associated with evaluation, but on the other hand, evaluative meaning might be 'evoked' by examining its context. In this study, I adopt a corpus-bases approach to the study of evaluation or stance in judicial discourse. This involves checking the corpus data for specific words and phrases that inscribe an attitude or stance towards an entity in the text.

The study of evaluative meanings in judicial discourse is still in its infancy. Some recent corpus-based studies include Heffer (2007), Mazzi (2008), Mazzi (2010), Finegan (2010), Szczyrbak (2014), Goźdź-Roszkowski \& Pontrandolfo 2013). Szczyrbak examines stancetaking strategies in a corpus of US Supreme Court opinions. The analysis is informed by du Bois's (2007) interactional concept of stance and the two related notions of epistemicity and evidentiality. Both Mazzi (2008) and Finegan (2010) examine the use of adverbials of stance in judicial discourse. The former study focuses 
on selected eight stance adverbs (e.g. apparently, clearly, etc.) analyzed in a corpus of 98 equity judgments of the Chancery Division of the High Court of Justice of England and Wales. In the latter, Finegan (2010) examines judicial attitude by focusing on adverbial expressions of attitudinal stance and emphasis. Heffer (2007) draws upon the systematic-functional lexical-semantic appraisal framework of judgment (Martin and White 2005) to examine the linguistic construal of evaluating witnesses and defendants by trial lawyers and judges. In doing so, Heffer investigates a large corpus of official court transcripts. Mazzi (2010) views evaluation as a deep structure and a prominent aspect of the way in which judges construct their argumentative positions (p.374). In his corpus-based study, Mazzi investigates evaluative lexis in the judicial discourse of US Supreme Court written opinions. By focusing on the single discourse element of 'this/these/that/those + the labelling noun', he provides some corpus evidence to demonstrate that abstract nouns such as, for example, attitude, difficulty, process, reason, etc. have both encapsulating and evaluative function when found in this pattern in the judicial opinions. Goźdź-Roszkowski \& Pontrandolfo (2013) and Goźdź-Roszkowski (2018) belong to those very few studies that begin to explore evaluation from a cross-language perspective. The present study continues to explore this research direction.

\section{Institutional Context: United States Supreme Court and Poland's Constitutional Tribunal}

Despite the obvious differences between the Common Law and the Continental Civil Law, the Supreme Court in the United States and the Constitutional Tribunal in Poland share some similarities with respect to their roles and functions. The US Supreme Court is the highest court in the United States. It consists of the Chief Justice and eight Associate Justices who are nominated by the president and confirmed by the Senate. Its primary task is to exercise appellate jurisdiction and to serve as the final arbiter in the construction of the Constitution of the United States by providing a uniform interpretation of the law. Appellants must file a petition for writ of certiorari, i.e. they ask the Court to hear their appeal. The certiorari can be either 
granted or denied. If it is granted, the Court will deliver one of the following opinions: per curiam opinion (unanimous), majority (opinion shared by the majority), plurality (final outcome agreed to by majority but for differing reasons). Individual judges (referred to as justices) can also write their separate opinions, which are either concurring (agreeing with the majority decision for different reasons) or dissenting opinion (disagreeing with the majority). It is not possible to appeal from a S.C. decision. The decisions are binding in all jurisdictions in the United States but the Supreme Court may overrule its own decisions ${ }^{1}$.

Poland's court system is a complex four-level hierarchy with regional, district, appellate and the highest court. The Constitutional Tribunal (Pol. Trybunat Konstytucyjny) stands apart from this hierarchy resolving disputes related to the constitutionality of actions undertaken by public institutions and its main task is to ensure the compliance of statutory law with the Constitution of the Republic of Poland. The Constitution of 2 April 1997 recognizes four areas of the Constitutional Tribunal's jurisdiction:

1) the review of norms (both abstract and specific; a posteriori and a priori - a particular procedure for reviewing the norms is adjudicating on constitutional complaints;

2) settling disputes over authority between the central constitutional organs of State;

3) determining whether purposes or activities of political parties are in conformity with the Constitution;

4) determining whether or not there exists an impediment to the exercise of the office by the President of the Republic.

One feature that is shared by both the US Supreme Court opinions and the judgments given by the Constitutional Tribunal is the focus on justifications used in the judicial decision-making. In terms of textual space, legal justification is located in the opinion part of the courts decisions. Opinions delivered by the Supreme Court of the United States (SC) generally consist of four major parts (Brostoff and Sinsheimer 2003): (1) Headnote - which includes the names of the parties, identification of parties (their role in the proceedings, i.e. petitioner, respondent), an identification of the court in which the recorded case was heard, and the date of the opinion, (2) Procedural

\footnotetext{
${ }^{1}$ This part of the paper is based on Lee et al. 1999 and the US Supreme Court website www.supremecourt.gov
} 
History - this section contains a brief description of how the lowerinstance courts dealt with the case. It usually includes the basis for review, i.e. the reasons why the Supreme Court heard the case; (3) Holding - invariably signalled by the use of the word held, this section provides the decision (ruling) reached by the Supreme Court in a particular case ended with a disposition of the case (e.g. affirmed, vacated and remanded); (4) Opinion - unlike the previous sections which are usually prepared by a court clerk, this final part is authored by individual judges and it includes judicial argumentation provided in order to justify the decision reached by the court. It explains the law as applied to the case and provides the reason on the basis of which the decision is made.

The macrostructure of a Constitutional tribunal judgment is to some extent similar. It consists of a headnote (Pol. komparycja), tenor, which contains a disposition of the case, i.e. the court's decision (roughly, this part corresponds to holding in S.C. opinions) and justification of judgments. Justifications given by the Constitutional Tribunal have a fixed structure which consists of three parts. First, there is a historical part (część historyczna) which refers to all the documents pertinent to a given case. In this part, the contents of an application (petition) and its basis are described. This part also provides the details of a charge and the challenged regulation as well as the positions taken by each of the interactants (parties to the proceedings) along with their most important arguments. The second part called "at the trial" (na rozprawie) reports all material circumstances which occurred between the first court hearing and the verdict. The third part focuses on the admissibility of a petition (ocena dopuszczalności wniosku), a specific constitutional issue, reviewing standards (wzorzec kontroli), relevance of the grounds for an application (ocena zasadności wniosku), etc. Finally, separate opinions (if any) are provided.

\section{Material and Method}

This study is based on two collections of data. The first one consists of 113 different opinions of the Supreme Court of the United States totaling 1,333,320 words and randomly sampled from the period between 1999 and 2015 via FindLaw.com, a well-known legal 
information web portal providing free access to cases heard by the US Supreme Court. The Polish data comprises 95 different judgments handed down by the Constitutional Tribunal between 2001 and 2015 . The texts, which contain 1,303,141 words, were collected from the online database Internetowy Portal Orzeczeń, available at http://ipo.trybunal.gov.pl.

In this study, I adopted a method whereby a targeted search is based on a grammar pattern: a grammar pattern of nouns followed by the appositive that-clause as the core item. Prior to the analysis, the corpus of US opinions was POS tagged using Wmatrix software (Rayson 2008) and the sequence NOUN + that was searched. The search was limited to nouns that occur at least 5 times per 1,000,000 words. The retrieved instances were then manually checked to ensure that the nouns are indeed followed by an appositive that-clause and not by the relative pronoun that (see Hunston \& Francis 2000: 98-99). Additionally, each noun had to be found in at least five different opinions in an attempt to reduce bias resulting from judges' idiosyncratic style of writing. As the next step, I selected four nouns for further study and these are argument, assumption, view and notion. Previous research (Goźdź-Roszkowski \& Pontrandolfo 2013; GoźdźRoszkowski forth.) suggests that these nouns are marked for their high evaluative potential in judicial writing and the nouns are used to signal what could be called 'sites of contentions', i.e. judges tend to select certain stance nouns to challenge propositions they deal with in ther argumentation.

In order to address the question whether the same discursive regularity occurs in Polish judicial texts, four corresponding Polish nouns were selected: argument, założenie, poglad, and twierdzenie. The Polish nouns were selected as prima facie dictionary equivalents using the English-Polish Dictionary PWN-Oxford (LindeUsiekniewicz 2004). This stage of analysis involved carrying out a targeted search (using the WordSmith Tools 5.0) for all instances of these nouns (including their declensional variants, i.e. argument argumentu, argumentem, etc.) in the text corpus. The retrieved instances were then manually checked to ensure that the nouns are indeed found in the comparable grammar pattern whereby the nouns are followed by $\dot{z} e$ or $i \dot{z}$ (the complementizer that in English corresponds to two variants in Polish: $\dot{z} e$ and $i \dot{z})$. The next stage involved scrutinising concordance lines centered around the four nouns in order to identify their collocational patterns. The obtained 
co-occurrence patterns were interpreted in functional terms. Sentence examples in Polish were glossed in English. The translation is literal and it only covers those relevant parts in which a particular phrase is found.

\section{Results and discussion}

argument that and argument, $\dot{z} e$

I first turn to examine the English data and start with the noun argument. Not surprisingly, this noun is very frequent in judicial argumentation. It appears 141 times per milion words in the corpus of Supreme Court opinions and barely 12.4 times per milion words in the academic section of the Corpus of Contemporary American English. In the largest (35\%) proportion of all the instances when argument that is found in the corpus of US S.C. opinions, it co-occurs with value-laden language items representing different parts of speech.

(1) This Court finds unpersuasive the argument that, even with those limits, par. 2(B) must be held preempted at this stage.

(2) Petitioner's argument that a sanction order is effectively unreviewable on appeal from a final judgment suffers from at least two flaws

(3) The availability of state judicial review defeats the Government's argument that , absent EPA's oversight, there is a legal vacuum where BACT decisions are not subject to review.

What is common to the three sentence examples shown as excerpts 1-3 is their evaluative function. The evaluation is expressed either by attributing it to a specific legal actor, usually it is the court en bloc, as in example (1) or it is averred by individual judges as in (2) and (3). While arguments remain the target of evaluation, the legal actors who advance them are often identified (e.g. petitioner's argument that, Government's argument that). Such evaluation is expressed overtly and it is usually negative. Judges also express their stance by indicating whether they accept or reject a given argument. This function is realized through a much more restricted lexis but it is also very common.

(4) We do not accept, furthermore, respondents' argument that laches should apply because the motions filed by the 
Government following the District Court's denial of its motion to dismiss amounted to little more than dilatory tactics to "delay and obstruct the proceedings."

Characteristically, the negative stance in a majority opinion is either averred by the judges and signalled through the use of the collective 'we' or attributed as in example (5):

(5) The court considered and rejected the State's argument that Sylvia's statement was reliable because it coincided with petitioner's to such a degree that the two "interlocked".

In most cases, arguments are ascribed to specific parties and/or legal actors. In sum, judicial stances and evaluations are present in over $70 \%$ of all the instances when argument is used in the opinions. In the remaining cases, judges refer to arguments as the basis or cause for argumentation (13\%). Arguments are also confirmed (7\%) and indicated as existing or not (9\%). Examples 6-8 illustrate these uses:

(6) While Stumpf's mitigation case was premised on the argument that Stumpf had not shot Mrs Stout, that was fully consistent with his plea of guilty to aggravated murder.

(7) Standing alone, the subsection supports the Commissioner's argument that a signatory operator is necessarily a member of a group of corporations that includes itself.

(8) First, there is the argument that par. 4001(a) does not even apply to wartime military detentions.

I now turn to examine data related to the corresponding Polish phrase argument, $\dot{z} e$. There are 30 occurrences of this phrase in the Polish corpus. The co-texts of both argument that and argument, $\dot{z} e$ share a similarity in that both phrases tend to be used to assess the argumentation of parties and legal actors. In almost half (14) of all the instances, propositions labelled as arguments are overtly evaluated as shown in examples 9-11.

(9) Nietrafny jest również argument, ̇̇e sądy nadały zaskarżonym przepisom treści normatywne niezgodne $\mathrm{z}$ art. 64 ust. $2 \mathrm{w}$ związku $\mathrm{z}$ art. 2 Konstytucji. [The argument that is ... incorrect].

(10) Minister Finansów podkreślił bezzasadność argumentu, że kwota oszczędności wynikających $\mathrm{z}$ niepodwyższenia płac sędziów jest minimalna. [The Finance Minister stressed that the argument that is ... groundless]. 
Tym samym Trybunał uznaje za nieuzasadniony argument Prezydenta RP, że kwotowa metoda waloryzacji podważa celowość podjętych $\mathrm{w}$ przeszłości inicjatyw przez świadczeniobiorców.

The evaluative lexis is however much more restricted in Polish judgments than in American opinions. In the former, arguments are usually assessed using a value-laden adjective signalling that a given argument is either justified or not. This is in line with Królikowski's (2015) observation that the language of justification in Constitutional Tribunal judgments is is becoming increasngly standardized. Another point of similarity is that the evaluation is either averred by the judges as in (9) or it is attributed to a specific legal actor (10) or the court en bloc (example 11). The other use of argument, $\dot{z} e$ (with 5 occurrences) is axiologically neutral and it introduces an argument of another legal actor or a petitioner (wnioskodawca). In example 12 below, the Speaker ofthe Sejm (Poland's lower house of parliament) puts forward an argument as one of the parties to the legal proceedings. ${ }^{2}$

Marszałek podniósł argument, że mimo iż obecnie brzmienie ustawy o świadczeniach rodzinnych w większym stopniu realizuje ten postulat, to nie można uznać, że dotychczasowa regulacja prowadziła do rzeczywistego, i to niezależnego od postępowania osób zainteresowanych, naruszenia ich praw wynikających z art. 69 Konstytucji. [Speaker of the Sejm put forward the argument that ...].

Some arguments may also be called upon to introduce different voices into a legal argumentation, some of which may not be directly involved as parties. Example (13) shows how an argument comes from the community of prosecutors. Such argumentation serves the purpose of strengthening legal justification contained in the judgment.

To ze strony środowiska prokuratorskiego podnoszony jest argument, że inne środki o charakterze nie izolacyjnym zwłaszcza wobec oskarżonych o najpoważniejsze przestępstwa - cechuje $\mathrm{z}$ ich natury realna słabość i

\footnotetext{
${ }^{2}$ The presence of the Speaker is very common in proceedings before the Constitutional Tribunal given that one of the main competences of the Tribunal is to examine the constitutionality of legislative acts.
} 
nieskuteczność [It is the prosecutors who raise the argument that ....].

Just as their American counterparts, the Tribunal's judges also signal their stance by rejecting or accepting arguments but there are only two occurrences of this use.

W tej sytuacji należy odrzucić argument, że opłaca się reakcja ustawodawcza nawet przy nikłym statystycznie zjawisku, jeśli można $\mathrm{w}$ ten sposób uzyskać lepszy efekt merytoryczny. [one should reject the argument that...].

assumption that and zatożenie, że

In general English, the noun assumption is usually used to signal likelihood (Biber et al. 1999: 648 - 651). In the corpus of S.C. opinions it occurs twice as frequently as in the academic section of COCA (42.7 and 20.5 time per milion words, respectively). The analysis shows that judges tend to use assumption that to express two major discourse functions. The largest proportions of instances (56\%) where this phrase is found is used to indicate causal relations. More specifically, assumptions are often construed as foundations for other propositions. This use is reflected in the strong co-occurrence between assumption that and the preposition on. Indeed, the phrase frame on + an/that/ adjective + assumption accounts for half of all the instances of assumption that. Examples (15) and (16) illustrate this point:

(15) But such a claim does not help the FCC, for relevant precedent makes clear that, when faced with ambiguity, we are to interpret statutes of this kind on the assumption that Congress intended to preserve local authority.

(16) Justice Stevens' contrary conclusion is predicated on the erroneous assumption that the ordinance proscribes large amounts of constitutionally protected and/or innocent conduct. In (15), the proposition marked as assumption serves to show the basis for statutory interpretation. It is worth noting that the larger co-text contains another epistemic noun claim used to assess and address an argumentative point (such a claim does not help the FCC). In a similar vein, in example (16) assumption is indicated as the basis for a conclusion made in a dissenting opinion of a Supreme Court judge. In addition, the assumption is immediately evaluated as erroneous but, arguably, the negative evaluation concerns also the conclusion made by the judge. His conclusion is linked directly to assumption, which indicates a weak epistemic status of this 


\section{Stanisław GOŹDŹ-ROSZKOWSKI: Signalling Sites...}

proposition. Labelling the proposition as assumption amounts to evaluation because it aligns the proposition with a construed world in which it cannot be subjected to immediate verification (GoźdźRoszkowski 2018: 144). However, in most cases found in this category, assumption is referred to non-evaluatively as the basis for other propositions. The other sizeable functional category includes instances when assumptions are overtly evaluated (25\%). This is illustrated in examples (16) and (17) below.

It is a naive assumption that the failure of a bill to make it out of committee, or to be adopted when reported to the floor, is the same as a congressional rejection of what the bill contained.

(18) The commentary's assumption that the terms "properly constituted" and "regularly constituted" are interchangeable is beyond reproach.

Other much less frequent functions include 'result', 'confirmation' and 'existence'. When we turn to consider the co-texts of the Polish equivalent phrase zatożenie, $\dot{z} e$, it is easy to notice that this phrase is used in essentially the same manner. There are 66 occurrences of this phrase in the corpus of Constitutional Tribunal judgments. Assumptions are referred to as basis or cause for other propositions in $51.5 \%$ ) of the cases. This is illustrated by the following two examples.

Obliczenia te oparte są na zalożeniu, że z ok. 100 tys. osób deportowanych na obszary II Rzeczypospolitej wcielone do III Rzeszy, do chwili obecnej żyje ok. 6 tys. osób. [These calculations are based on the assumption that (...)].

Zarzuty sądu pytającego są obecnie bezprzedmiotowe, gdyż jego argumentacja została oparta na założeniu, że niedopuszczalna jest sytuacja, w której ustawodawca pozbawił pewną grupę osób maksymalnie ukształtowanej ekspektatywy. [The charges put forward by the court are now pointless since its argumentation is based on the assumption that ....].

In a small proportion of ( 7 out of 34 ) cases, assumptions are both indicated as basis for other propositions and overtly evaluated. This echoes the discursive practice demonstrated in the case of the corresponding expressions in the Supreme Court opinions. Note, for 
example, how closely Example (21) corresponds to the sentence provided in (16) above:

(21) Tak sformułowany zarzut opiera się jednak na błędnym założeniu, że obie grupy ubiegających się o zwolnienie $\mathrm{z}$ kosztów sądowych powinny mieć zagwarantowane prawo do dwukrotnego rozpatrzenia ich wniosków przez niezależne i niezawisłe sądy. [This charge is based on the erroneous assumption that ...].

Propositions based on assumptions usually include zarzuty (charges), stanowisko (stance, position) and wywody (argument). In addition, what appears quite characteristic of Polish judicial writing is the use of assumptions as basis for marking logical relations between two propositions by stressing that a given proposition is the consequence or result of an assumption. This use found in $22.7 \%$ of all cases is usually expressed using the phraseological expression wyjść z założenia [make an assumption] but there are also other language items such as punkt wyjścia (point of departure) or the cooccurring noun konsekwencja employed for the same purpose:

Trybunał wyszedt $z$ założenia, wyrażanego $\mathrm{w}$ dotychczasowym orzecznictwie, że sposób określenia obowiązku W art. 84 Konstytucji został powierzony ustawodawcy zwykłemu. \{The Tribunal made an assumption expressed in the existing judicature that ...].

Punktem wyjścia dla tych orzeczeń było założenie, że (...) [Lit. The point of departure for these rulings was the assumption that ...].

Assumptions co-occurring with purely evaluative language items amount to $15 \%$ and they usually include value-laden negativelycharged adjectives such as kontrfaktyczne, kontrowersyjne, nieprawdziwe, nieprawidłowe, nietrafne, sprzeczne, nie $w$ petni odpowiada rzeczywistości, etc. Excerpts 24 and 25 provide additional contexts:

Co najmniej kontrowersyjne jest dla mnie podstawowe założenie Trybunału Konstytucyjnego, że moralność ... [The Constitutional Tribunal's assumption that $\ldots$ is controversial].

(25) W jego ocenie przepis ten przyjmuje kontrfaktyczne założenie, że nie został dokonany wybór sędziów, których kadencja upływa w roku 2015. 


\section{Stanisław GOŹDŹ-ROSZKOWSKI: Signalling Sites...}

In sum, it appears that assumptions in both American and Polish judicial writing are used as prime vehicles for construing foundations and showing logical correlations (or their absence) in legal argumentation. In addition, they are often evaluated.

view that and poglad, że

The phrase view that is yet another example of a noun which is by far more commonly employed in judicial discourse $(75.7 \%$ words per $1 \mathrm{~m}$ words) than in academic discourse provided in the COCA (19.3 words per $1 \mathrm{~m}$. words). In contrast to assumption that and argument that, there is no single dominant function associated with view that. Still, the largest proportion of all instances of view that co-occur with various linguistic manifestations of evaluation. Interestingly, unlike in the case of the nouns shown above, the evaluation tends to be neutral or positive:

(26) To be sure, I find much to commend the view that the Establishment Clause...

(27) Mills simply represented a straightforward application of our longstanding view that ...

In another $30 \%$ of cases, it emerges that views are used to signal stance by confirming or disconfirming them. This usually takes the form of accepting or rejecting them.

Recognizing this point, we previously rejected the view that a witness is not subject to confrontation if his testimony is "inculpatory only when taken together with other evidence."

Even if this history had some relevance, it would not support the view that Congress intended to insert a new value exception into the phrase "on account of".

The analysis shows that stance-related and evaluative language can be found with view that in $64 \%$ of the cases. Clearly, not all views are imbued with evaluation. In $20 \%$ of the cases, judges preparing their opinions merely report on what other legal actors think with regard to a particular issue.

(30) Finally, Wilson laid out his view that sovereignty was in fact not located in the States at all.

I recognize that some Members of the Court, now or in the past, have taken the view that the First Amendment simply does not permit Congress to legislate in this area. 
This neutral use of view that has been labelled as 'existence' because views are indicated as existing and no indication of an author's stance is provided. Example 31 shows how a judge in his dissenting opinion positions himself with regard to the argumentation put forward in the majority opinion. In the remaining $14 \%$ of the instances where view that is found in the corpus, it is indicated as cause or basis for some other proposition, e.g. a decision as in Example 32.

The Court's decision to dismiss the writ of certiorari as improvidently granted presumably is motivated, at least in part, by the view that the jurisdictional issues presented by this case do not admit of an easy resolution.

Turning now to the Polish counterpart, poglad, $\dot{z} e$ we first note its relatively high frequency of 241 instances. Interestingly, the phrase poglad, że displays a consistent collocational behaviour. In as many as 47 cases $(19,5 \%)$ poglad, $\dot{z} e$ co-occurs with a single verb podzielać (share). It is usually an institutional entity that shares a given view.

Trybunał Konstytucyjny podziela wyrażony w doktrynie pogląd, że przystąpienie do organizacji międzynarodowej oznacza przekazanie przez właściwe organy krajowe kompetencji do wykonywania władzy w zakresie działalności organizacji na rzecz jej organów. [Constitutional Tribunal shares the view expressed in the jurisprudece that (...)]

Prokurator Generalny podzielit pogląd RPO, że pkt 3.1.2 załącznika nr 1 nie spełnia konstytucyjnego warunku jego wydania (...). [Attorney General shared the view of the Ombudsman that ...].

It is also the preferred way of signalling concurrence by individual judges in their separate opinions:

Podzielam pogląd, że w świetle orzeczenia w sprawie o sygn. K. 3/98, stanowi to wystarczający powód do stwierdzenia, że doszło do naruszenia zasad prawidłowej legislacji. [I share the view that (...)].

This concurring function is also realized by means of less frequent verbal collocates such as zgodzić się, (agree), akceptować (accept), przyjmować (receive), podtrzymywać (support), which amount to 18 occurrences.

(36) Trybunał zgadza się $\mathrm{z}$ poglądem wyrażonym przez Prokutarora Generalnego, że w odniesieniu do pierwszego ze 


\section{Stanisław GOŹDŹ-ROSZKOWSKI: Signalling Sites...}

wskazanych zarzutów analiza uzasadnienia wniosku nie dostarcza żadnych argumentów mogących potwierdzić zasadność sformułowanego zarzutu niekonstytucyjności art. 21 ust. $1 \mathrm{w}$ związku z art. 2 pkt. 5 u.e.p. [The Tribunal agrees with the view expressed by the Attorney General that ...].

The other major function centres around the collocational pattern which include the verb wyrazic (express). This is in fact the most frequent single verbal collocate (52 instances / 21.5\%).

Marszałek Sejmu wyrazit jednak pogląd, że obecnie obowiązujący w Polsce model środków zaskarżenia przyjęty w wykonaniu Rozporządzenia nr 44/2001 jest zgodny $\mathrm{Z}$ Konstytucją. [The Speaker expressed the view that (...)].

Wnioskodawca wyrazit pogląd, że zaskarżony przepis godzi także w zasadę nullum delictum sine lege certa. [The Petitioner expressed the view that (...)].

As examples 37 and 38 show, the phrase poglad, $\dot{z} e$ is used to report on how the interactants' are positioned with regard to a given legal issue. In terms of the textual structure of legal justification, this reporting use is commonly found in either the historical part or the part ,at the trial". This part of the justification serves to present the arguments of the parties to the proceedings and it precedes the argumentation of the Tribunal. In each case, the legal interactant is identified. Interestingly, there are also many cases where views are ascribed less directly.

W filozofii oraz piśmiennictwie prawniczym zakorzeniony jest pogląd, że przesłanka „moralności” odsyła do norm moralnych uznanych $\mathrm{w}$ danym społeczeństwie $\mathrm{i}$ odnoszących się do stosunków międzyludzkich. [In philosophy and legal writing, there is a deeply-rooted view that ...]

W judykaturze ETPC utrwalony jest pogląd, że prawo do sądu byłoby iluzoryczne, gdyby wewnętrzny system prawa państwa umożliwiał to, iż prawomocne orzeczenie jest nieskuteczne ze szkodą dla jednej ze stron. [In the judicature of the ECHR, there is a long-standing view that ...].

Other similar lexical items include the dominuje (dominate), przeważa, panuje (prevail) which account for $8 \%$ of the cases. Overall, this use of poglad, ze is very common (almost $30 \%$ of the cases) and it serves to indicate the existence of views, esp. those present in legal literature, the legal doctrine or the judicature (usually 
of the Constitutional Tribunal). It could be argued that the examples provided above are not totally deprived of an evaluative value. If a view prevails then this gives an additional authority.

Finally, there are relatively few cases when poglad, $\dot{z} e$ is used to overtly evaluate a particular proposition (6\% of the cases):

Tym samym, niezasadny byłby pogląd, że kwestionowana regulacja prowadzi do naruszenia konstytucyjnego zakazu podwójnej karalności. [the view that (...) would be unjustified].

Trybunał stwierdził, że zbyt daleko idacy byłby pogląd, że Konstytucja ograniczyła swoją normatywną treść tylko do nałożenia na ustawodawcę obowiązku przyjęcia przepisów $\mathrm{w}$ tej dziedzinie bezpieczeństwa i higieny pracy. The Tribunal said that the view that (...) would go too far].

notion that and twierdzenie, że

Finally, two nouns are examined which are not semantically equivalent but they display a very high degree of functional similarity. The Polish noun twierdzenie corresponds to the English claim or assertion. Both these nouns belong to the linguistic repertoire of argumentative language. These two nouns are similar in that evaluation is the dominant discourse function. Below, their phraseological behaviour is briefly examined. The noun notion when followed by the that-clause is relatively infrequent in the corpus of S.C. opinions. Still, its rounded frequency of 27 occurrences per one milion words is largely on a par with its freqency in the COCA (24.2). The analysis shows that evaluation is the dominant discourse function as it accounts for as much as $64 \%$ of all the instances of this phrase found in the corpus. In the remaining cases, notions signal causal relations $(21 \%)$ and confirmation (15\%). The closer scrutiny of the cotexts in which notion that is found shows that the phrase notion is the preferred way of expressing unfavourable and unmitgated evaluation, esp. when the phrase is found in the subject position:

The notion that media corporations have constitutional entitlement to accelerated judicial review of the denial of zoning variances is absurd.

(44) The notion that FIFRA contains a nonambiguous command to pre-empt the types of tort claims that paralel FIFRA's misbranding requirements is particularly dubious 
given that just five years ago the United States advocated the interpretation that we adopt today.

Notions are also confirmed or disconfirmed as in the following example (45) which signals a lack of support from Justice Ginsburg, who delivered the opinion of the Court. It is worth pointing out that while the notion itself is not evaluated, the proposition contained in the that-clause achieves a clearly evaluative effect by using the negatively-charged verb scavenge to imply that the defendant could experience difficulty in obtaining access to some evidence related to the case:

Our decisions lend no support to the notion that defendant must scavenge for hints of undisclosed Brady material when the prosecution represents that all such material has been disclosed.

Notions are also frequently rejected or discounted. Notions may also be the basis for other propositions some of which signal contention:

The contention is premised on the notion that the phrase "original jurisdiction of all civil actions"means different things in par. 1331 and par. 1332.

The Polish phrase twierdzenie, $\dot{z} e$ is found 66 times in the Tribunal's judgments. The analysis shows that in $77 \%$ of all the instances, it co-occurs with language items which are either explicitly evaluative by directly qualifying the noun twierdzenie or which indicate stance by signalling (dis)agreement with claims made by other interactants. The following adjectives and phrases have beed indentified as most common in the first case, niedopuszczalne, nieprawidlowe, nieuprawnione, nieuzsadnione, trafne, zbyt daleko idace, nie znajduje (konstytucyjnego) uzasadnienia. These are illustrated in Example 47 and 48.

Nieuprawnione jest także twierdzenie Ministra Sprawiedliwości, że ustawową podstawą do przetwarzania przez kuratora danych, o których mowa (...) [Unjustified is the claim made by the Justice Minister that (...).

(48) Skoro ustawa o świadczeniach rodzinnych nie rozstrzyga, na które kolejne niepełnosprawne dziecko w rodzinie przysługuje kwota zwiększenia dodatku z tytułu samotnego wychowywania dziecka, nieprawidtowe jest twierdzenie Rzecznika, że art. 11a ust. 4 ustawy narusza art. 
69 Konstytucji [(...) incorrect is the claim put forward by the Ombudsman that (...)].

As in the case of the other nouns discussed above, stance is also expressed by indicating one's agreement or disagreement. This is usually realized using the modal verb móc plus negation: nie można:

Nie można zgodzić się z twierdzeniem wnioskodawcy, że kwestionowany przepis nakłada na kuratora sadowego (...); [One cannot agree with the Petitioner's claim that...].

Another preferred way of challenging assertions is to indicate that it does not deserve support:

$\mathrm{Z}$ uwagi na powyższe nie zastuguje na poparcie twierdzenie, że $\mathrm{w}$ społeczeństwie polskim bezwzględny zakaz uboju rytualnego jest konieczny do ochrony szeroko rozumianej moralności. [the claim that ... does not deserve support].

(51) Na aprobatę nie zasługuje również pogląd odwołujący się do zasady swobody umów, a także twierdzenie, że przyjęte przez ustawodawcę rozwiązanie korzystnie wpływa na cenę gruntu podczas jego sprzedaży. [the claim that (...) does not deserve approval.

One more phraseologically distinct pattern includes the forms uzasadniać / uzasadnienie (justify / justification) co-occurring with twierdzenie, że:

Nie ma zatem konstytucyjnego uzasadnienia twierdzenie, $\dot{z} e$ (...) [There is no constitutional justification for the claim that ....].

W tej sytuacji zaniechanie wyrażenia opinii przez podmiot uprawniony nie może uzasadniać twierdzenia, że (...) [In this case, failure to express opinion by an entitled entitiy cannot justify the claim that ...].

These examples illustrate the semantic and functional regularity that this pattern is primarily used to express negative stance. Only one counter-example was found. This brief analysis shows that twierdzenie, że belongs to the repertoire of challenging propositions in legal argumentation. 


\section{Summary and Conclusions}

Legal justification is central to judicial decision-making irrespective of a legal system. While justification may play different roles in different legal systems, it invariably reflects the motives behind judicial decisions and judges' way of reasoning. Arguments of various legal interactants are presented and carefully examined to check the status and validity of claims made by applicants.

The findings presented in this paper corroborate the claim that evaluative language is inherent in legal reasoning and argumentation and they provide further evidence that judges tend to favour certain linguistic expressions to make assessments and express their stances. One such linguistic resource is provided by head nouns which take a nominal complement in the form of a that-clause. While only a limited number of nouns have been taken into account in this study, the findings, based on bilingual data, unequivocally show that this grammar pattern tends to be associated with evaluative meanings. Evaluation accounts for the largest proportions of instances where each of the nouns is used in the data (except for assumption and its Polish counterpart założenie). Clearly, there are other discourse functions peformed by these phrases, such as indicating casual relations, existence or confirmation but evaluation remains the dominant one. Challenged propositions in legal argumentation are likely to be labelled as arguments, assumptions, notions or views. This discursive practice seems to hold true in both American and Polish judicial discourse. These findings help to identify 'sites of contentions', i.e. textual spaces where judges express their (dis)agreements over specific points of law. The corpus-based functional analysis helps to reveal the general phraseological similarity between the two sets of data suggesting that American and Polish judicial writing is underpinned by essentially the same epistemological assumptions. Irrespective of the differences between the two legal cultures and their major judicial institutions, there are certain patterns of linguistic expression exploited in judicial rhetoric for basically the same reasons. On the other hand, there are some differences in the way the nouns behave phraseologically. Polish nouns tend to show less collocational variation and they are found performing fewer discourse functions. For example, the noun poglad co-occurs with only two verbal collocates (podzielać and wyrazić) in 
as much as $40 \%$ of the cases. The Polish argument is associated with two discourse functions: evaluation and existence, while its American equivalent co-occurs with four different functions.

This study is obviously limited in some respects. It considers only a small proportion of nouns and it focuses on a single pattern, where the noun is followed by the that-clause. One immediate way of extending the analysis is to examine a larger set of nouns in their entire complementation patterns. The other research direction could focus on identifying other common structures and phraseologies employed by judges in their justifications with a view to building a picture of common epistemological practices in judicial discourse across different legal cultures and languages.

\section{References}

Biber, Douglas, Johansson, S., Leech, Geoffrey, Conrad, Susan, and Finegan, Edward. 1999. The Longman Grammar of Spoken and Written English. London: Longman.

DiMatteo, Larry. 2015. Legal justification in Anglo-American Common Law. In: Uzasadnienia decyzji stosowania prawa, ed. Iwona Rzucidło-Grochowska and Mateusz Grochowski., 512-524. Warsaw: Wolters Kluwer

Du Bois John. 2007. The stance triangle. In Stancetaking in discourse: subjectivity, evaluation, interaction, ed. Englebretson R.,139182. Amsterdam: Philadelphia.

Finegan, Edward. 2010. Corpus linguistics approaches to 'legal language': adverbial expression of attitude and emphasis in Supreme Court opinions. In: The Routledge Handbook of Forensic Linguistics, ed M. Coulthard \& A. Johnson, 65-77. London \& New York: Routledge.

Goźdź-Roszkowski, Stanisław and Hunston, Susan. 2016. Corpora and beyond - investigating evaluation in discourse: introduction to the special issue on corpus approaches to evaluation. Corpora. Vol. 11 No. 2; 131-141

Goźdź-Roszkowski, Stanisław and Gianluca Pontrandolfo. 2013. Evaluative patterns in judicial discourse: a corpus-based phraseological perspective on American and Italian criminal 
judgments". International Journal of Law, Language and Discourse, vol 13, Issue 2, pp. 9-69.

Goźdź-Roszkowski, Stanisław. (forth.) Between Corpus-based and Corpus-driven Approaches to Textual Recurrence. Exploring Semantic Sequences in Judicial Discourse. In: Patterns in Text. Corpus driven methods and applications, ed. Kopaczyk, J. Tyrkkö, J. Amsterdam: John Benjamins.

Goźdź-Roszkowski, Stanisław. 2018. Facts in Law. A comparative Study of fact that and its phraseologies in American and Polish judicial discourse. In: Phraseology in Legal and Institutional Settings. A Corpus-based Interdisciplinary Perspective, ed. Goźdź-Roszkowski, S. and G. Pontrandolfo, 143-159. London and New York: Routledge.

Heffer, Chris. 2007. Judgement in Court: Evaluating participants in courtroom discourse. In Language and the Law: International Outlooks, ed. K. Kredens and S. Goźdź-Roszkowski, 145-179. Frankfurt am Mein: Peter Lang GmbH.

Hunston, Susan. and Francis, Gill. 2000. Pattern Grammar: A Corpus-Driven Approach to the Lexical Grammar of English. Amsterdam: John Benjamins.

Hunston, Susan and Geoff Thompson 2000 (eds.) Evaluation in Text. Authorial Stance and the Construction of Discourse. Oxford: OUP.

Królikowski Jakub (2015) „Uzasadnienia orzeczeń Trybunału Konstytucyjnego". In: Uzasadnienia decyzji stosowania prawa, ed. Iwona Rzucidło-Grochowska \& Mateusz Grochowski, 427-439. Warsaw: Wolters Kluwer.

Lee, Debra, Hall, Charles and Marsha Hurley 1999. American Legal English. Using Language in Legal Contexts. Ann Arbor: The University of Michigan Press.

Linde-Usiekniewicz, Jadwiga. 2004. Wielki Stownik Polsko-Angielski. Polish English Dictionary. Warszawa: Wydawnictwo Naukowe PWN and Oxford University Press.

Martin, James and White, Peter. 2005. The Language of Evaluation: Appraisal in English. London: Palgrave.

Mazzi, Davide. 2008. 'I first have to decide whether there were any notes in the first place. I consider that there probably were: adverbials of stance in equity judges' argumentation'. Textus XXI: 505-522. 
Mazzi, Davide. 2010. 'This Argument Fails for Two Reasons... A Linguistic Analysis of Judicial Evaluation Strategies in US Supreme Court Judgements'. International Journal for the Semiotics of Law 23 No. 4: 373-385.

Partington, Alan, Alison Duguid and Charlotte Taylor. 2013. Patterns and Meanings in Discourse. Theory and practice in corpusassisted discourse studies (CADS). Amsterdam: John Benjamins Publishing Company.

Scott, Mike. 2011. Wordsmith Tools available at http://www.lexically.net/wordsmith/version5

Szczyrbak, Magdalena. 2014. Stancetaking strategies in judicial discourse: evidence from US Supreme Court opinions, Studia Linguistica Universitatis Iagellonicae Cracoviensis 131: 1-30. 